University of Nebraska - Lincoln

DigitalCommons@University of Nebraska - Lincoln

Papers in the Earth and Atmospheric Sciences

Earth and Atmospheric Sciences, Department

4-1935

\title{
THE NEBRASKA EARTHQUAKE OF MARCH 1, 1935
}

Alvin Leonard Lugn

University of Nebraska-Lincoln

Follow this and additional works at: https://digitalcommons.unl.edu/geosciencefacpub

Part of the Earth Sciences Commons

Lugn, Alvin Leonard, "THE NEBRASKA EARTHQUAKE OF MARCH 1, 1935" (1935). Papers in the Earth and Atmospheric Sciences. 365.

https://digitalcommons.unl.edu/geosciencefacpub/365

This Article is brought to you for free and open access by the Earth and Atmospheric Sciences, Department of at DigitalCommons@University of Nebraska - Lincoln. It has been accepted for inclusion in Papers in the Earth and Atmospheric Sciences by an authorized administrator of DigitalCommons@University of Nebraska - Lincoln. 


\section{DISCUSSION}

\section{THE NEBRASKA EARTHQUAKE OF MARCH I, I935}

RESIDENTS within an area of 50,000 to 75,000 square miles in Nebraska, Iowa, Missouri and Kansas were awakened by mild but distinct earth tremors at 5:00 and 5:03 A.M. on March 1. No damage of any importance has been reported. Two distinct tremors occurred, each lasting about 10 seconds, about 3 minutes apart.

In a few cases vases or other small objects were shaken off from small unsteady tables. The writer was awakened by the second tremor. The vibrations seemed to oscillate in an east-west direction. The bed vibrated in this direction and the spring was tapping the footboard when the writer awakened. The mirrors of a high vanity dresser standing against the east wall of the room were also loudly clattering against the wall.

The writer also noted a very distinct rumbling accompanying the tremors. It greatly resembled the rumble of a heavy freight train. Many other persons also noted the rumble, and some have stated that the rumble preceded the actual tremors by a few seconds. The writer at first thought that the rumble might be that of a train, but it ceased immediately when the tremors stopped. This was noted at the time. Subsequently, other persons have reported the rumble from country homes too remote from trains or street traffic to leave any room for doubt of its connection with the earthquake.

The rumble was so distinct that the writer feels it should be specially noted. Since the mechanical vibrations which constitute the tremors may be and commonly are of audio-frequency, sound is a natural accompaniment of an earthquake. However, the sound vibrations set up by earth tremors are frequently masked by other noises and the commotion that often accompanies such events. The quiet of the morning hour and the mildness of the tremors, unaccompanied by the noise of crumbling masonry, et cetera, makes the record of the rumbling in the Lincoln, Nebraska, area of considerable interest.

The record sheets of the automatic pressure recorders for the 28-mile pipeline from Ashland to Lincoln, Nebraska, which supplies water from the city of Lincoln, indicated abnormal and peculiar pressure variations during the earthquake.

As far as known, the greatest intensity seems to have been noted at Falls City, Lincoln and to a less degree at Omaha, Nebraska, and at St. Joseph, Missouri.

The writer is in complete agreement with other geologists and seismologists that the tremors were caused by a slight slip along the old fault which de- limits the east side of the buried Nemaha mountains. The Nemaha mountain ridge is a faulted ridge of preCambrian rock, for the most part Sioux quartzite, which extends from north to south under eastern Nebraska and Kansas. It has been described and discussed recently by the writer ${ }^{1}$ in connection with the pre-Pennsylvanian structure and stratigraphy of $\mathrm{Ne}$ braska.

The top of the escarpment of this buried pre-Cambrian mountain ridge stands about 1,500 feet above the downfaulted basin east of the fault at Nehawka, Nebraska, and it is more than 3,100 feet high in the vicinity of $\mathrm{Du}$ Bois, Nebraska, at the NebraskaKansas state line. This entire mountain range is completely buried under Paleozoic and younger sedimentary formations. The highest point on the ridge in Nebraska is at $\mathrm{Du}$ Bois, where it comes to 558 feet below the surface. It rises about 100 feet higher a few miles south in Kansas. The crest is buried under 1,567 feet of Paleozoic sedimentary formations at Nehawka, and under 1,870 feet of strata at Papillion, Nebraska.

The Nemaha ridge is believed first to have come into existence by folding and faulting during the orogeny which brought the Proterozoic era to a close, that is, during the disturbance which is commonly known as the Killarney-Grand Canyon revolution. The Nemaha mountains are thought to have been a spur from the Sioux Falls "high," and there may even have been a structural as well as a generic connection between these ancient north mid-continent structural features and the long and prominent Killarney mountains, which are supposed to have extended from Minnesota northeastward to the Atlantic.

The first faulting is thought to have occurred at that time, but there is ample evidence that major displacements also took place subsequently during the Paleozoic era following the Ordovician, Silurian, Devonian (?), Mississippian and Permian periods. Apparently the last major displacement took place during or at the close of the Permian period, for Permian formations are faulted with a throw of from 200 to 250 feet in the Humboldt fault in Richardson County. The vertical displacement of the St. Peter sandstone in the vicinity of Nehawka and Nebraska City is at least 1,000 feet, and of the pre-Cambrian Sioux quartzite at least 1,500 feet. The displacement of the older formations is no doubt much greater than this farther south along the ridge. This indicates that the older formations have been further displaced at each later disturbance so that the throw on such formations as the St. Peter has been cumulative during very long periods of geologic time.

1 A. L. Lugn, Bull. Amer. Assoc. of Petrol. Geol., Vol. 18, No. 12, pp. 1597-1631, December, 1934. 
The Nemaha ridge remained an island in the Paleozoic sea, or perhaps it was a chain of islands, while sediments were piling up around and against it. The succeedingly younger systems of rock rest unconformably against the Sioux quartzite and granite by overlap. However, as indicated above, this simple relationship has been complicated by several stages of pronounced faulting, in every case apparently along the same rift or fault zone, which first seems to have come into existence late in the pre-Cambrian.

There is no known evidence indicating that any important displacements have taken place along the Nemaha structure during the Mesozoic and Cenozoic eras. Several mild earthquakes have been experienced during the last hundred years in eastern Nebraska, all or most of them apparently related to this ancient Nemaha structure. It is interesting and significant that this very ancient topographic and structural feature has to a large degree dominated the structural and depositional history of eastern Nebraska and Kansas, and adjacent areas since pre-Cambrian time, and that it apparently is not yet entirely static.

It is evident, in view of the facts stated above, that the region affected by the recent tremors in all probability will experience mild disturbances from time to time. It is also possible but not very probable that it may sometime experience an earthquake of destructive intensity.

The late John R. Freeman ${ }^{2}$ regarded the Great Plains, an area of some 600,000 square miles, as the safest from earthquake danger in the United States. However, he thought it probable that this whole great region might experience one earthquake of destructive intensity in a century. Such a "destructive" earthquake would pretty completely wreck things within an area of about 2,500 square miles, according to Freeman. Thus, according to this probability, such centers as Kansas City, St. Joseph, Omaha or Lincoln, or any other single area of 2,500 square miles in the entire Great Plains region, as defined by Freeman, might expect one "destructive" earthquake in 24,000 years.

UNIVERSITY OF NEBRASKa

A. L. LUGN 